\title{
HUBUNGAN KADAR ANTIBODI RESEPTOR ASETILKOLIN DENGAN DERAJAT KEPARAHAN PENYAKIT MIASTENIA GRAVIS DI RS CIPTO MANGUNKUSUMO
}

\author{
ASSOCIATION BETWEEN LEVEL OF ACETYLCHOLINE RESEPTOR \\ ANTIBODY AND MYASTHENIA GRAVIS SEVERITY IN \\ CIPTO MANGUNKUSUMO HOSPITAL \\ Manfaluthy Hakim, * Fika Tiara, * Ahmad Yanuar, * Winnugroho Wiratman, * Luh Ari Indriawati, * \\ Astri Budikayanti, * Fitri Octaviana*
}

\section{ABSTRACT}

Introduction: Acetylcholine receptor (AChR) antibody is main antibody in pathogenesis of myasthenia gravis (MG). AChR antibody is an important diagnostic tests. Myasthenia gravis clinical features can be divided into ocular, generalized and bulbar MG. Severity of $M G$ can be assessed based on $M G$ composite score (MG-cs).

Aim: To evaluate association between level of AChR antibody and MG severity based on MG severity in Cipto Mangunkusumo Hospital.

Methods: This was a descriptive-analytic cross-sectional study which were done at Cipto Mangunkusumo Hospital during January to November 2017. Inclusion criteria were MG patients aged 18-75 years old. Assessment of MG composite score and blood withdrawal were performed at the same time. The level of AChR antibody was measured by ELISA method.

Results: There were 72 subjects met inclusion criteria. Mean age was 43 years old (SD 12.56) with proportion higher in women (2.5:1). Ocular MG was the most initial symptom (79.2\%) and early onset was the most common(77.8\%). There were $59.7 \%$ subject who had seropositive AChR antibody. There was no significant association between seropositive AChR antibody and gender, age of onset, $M G$ type, MGFa classification, immunotherapy. There was no association between level of AChR antibody and MG-cs(p=0.727).

Discussion: There wasn't any association between level of AChR antibody and MG severity based on MG-cs.

Keywords: AChR antibody, $M G$ composite score, $M G$ severity

\section{ABSTRAK}

Pendahuluan: Antibodi reseptor asetilkolin (anti-AChR) merupakan antibodi utama dalam patogenesis penyakit miastenia gravis (MG). Pemeriksaan antibodi ini merupakan salah satu pemeriksaan penting dalam menegakkan diagnosa. Gambaran klinis MG dapat terbagi menjadi MG okular, MG generalisata dan MG bulbar. Tiap individu dapat memiliki derajat keparahan yang berbeda yang dinilai berdasarkan MG composite score (MG-cs).

Tujuan: Untuk mengetahui adanya hubungan kadar anti-AChR dengan derajat keparahan penyakit MG berdasarkan MG-cs di RS Cipto Mangunkusumo (RSCM).

Metode: Penelitian ini merupakan studi potong lintang yang melibatkan pasien MG di RSCM pada bulan Januari 2017- November 2017. Kriteria inklusi subjek ialah pasien yang telah didiagnosa MG berusia 18-75 tahun. Pemeriksaan kadar anti-AChR dengan metode ELISA. Penilaian MG-cs dilakukan bersamaan dengan pengambilan sampel darah.

Hasil: Didapatkan 72 subjek yang sesuai kriteria inklusi. Rerata usia subjek adalah 43 tahun (SD 12,56) dengan jenis kelamin perempuan lebih banyak (2,5:1). Gejala okular merupakan gejala terbanyak saat awitan $(79,2 \%)$ dan early onset MG lebih banyak ditemukan (77,8\%). Sebanyak 59,7\% subjek memiliki seropositif anti-AChR. Tidak ada perbedaan bermakna seropositifitas anti-AChR pada kelompok berdasarkan jenis kelamin, usia awitan, tipe MG, dan pemberian terapi imunosupresan. Tidak didapatkan hubungan bermakna antara kadar anti-AChR dengan MG-cs $(\mathrm{p}=0,727)$.

Diskusi: Kadar anti-AChR tidak berhubungan dengan derajat keparahan penyakit MG.

Kata kunci: Antibodi reseptor asetilkolin, derajat keparahan MG, MG-cs.

*Departemen Neurologi FK Universitas Indonesia/RSUPN Cipto Mangunkusumo, Jakarta. Korespondensi: manfaluthy.hakim@ui.ac.id

\section{PENDAHULUAN}

Miastenia gravis (MG) adalah penyakit autoimun yang disebabkan antibodi pada reseptor asetilkolin (acethylcholine receptor/AChR) di membran pascasinaps taut saraf otot (neuromuscular junction). Gejala klinis yang khas pada MG berupa kelemahan fluktuatif pada otot skeletal, okular maupun bulbar. ${ }^{1,2,3}$ Angka kejadian MG termasuk jarang namun prevalensi mulai meningkat seiring dengan peningkatan kemampuan diagnosis, terapi, dan umur harapan hidup. Prevalensi saat ini diketahui sekitar 24,9 sampai 131 per 1.000 .000 populasi 
dengan prevalensi paling tinggi pada perempuan usia 20-30 tahun. ${ }^{4}$

Miastenia gravis menimbulkan morbiditas dan mortalitas yang tinggi. Penelitian di Denmark menunjukkan bahwa mortalitas pasien MG dengan AChR seropositif lebih tinggi dibandingkan populasi normal. Sebanyak 302 meninggal dari 702 pasien MG yang diikuti dari tahun 2005 hingga 2009. Mortalitas pada pasien MG wanita lebih tinggi dibandingkan pria. ${ }^{5}$ Penelitian di Wuhan menunjukkan mortalityrate pasien MG sebesar 5,88\% serta berhubungan dengan derajat beratnya MG dan titer antibody $\mathrm{AChR} .{ }^{6}$

Diagnosis MG ditegakkan berdasarkan gambaran klinis, pemeriksaan serologi antibodi yang spesifik terhadap $\mathrm{MG}$ dan pemeriksaan elektroneurofisologi. ${ }^{2}$ Pemeriksaan repetitive nerve stimulation (RNS) memiliki sensitivitas yang lebih rendah dibandingkan dengan pemeriksaan serologi antibodi AChR (anti-AChR)., Pemeriksaan serologi antibodi belum merupakan hal yang rutin dilakukan sampai saat ini di Indonesia, sehingga penegakkan diagnosis hanya didasarkan anamnesa, pemeriksaan klinis dan elektroneurofisiologi.

Sebagian besar pasien MG (hingga 85\%) memiliki anti-AChR, sehingga dikatakan sebagai antibodi utama pada patogenesis MG. ${ }^{2,8,9}$ Anti-AChR seropositif tidak hanya ditemukan pada pasien MG onset dewasa, namun juga pada $>70 \%$ pasien juvenila MG ditemukan anti-AChR seropositif. ${ }^{10}$

Gambaran klinis MG dapat bervariasi pada masing-masing individu. Gejala awal umumnya berupa gejala okular dan sebagian besar dalam 2 tahun akan memberat menjadi generalisata, sedangkan sebagian kecil tetap terbatas pada MG okular. Derajat keparahan penyakit MG dapat dinilai dengan beberapa skor atau klasifikasi, diantaranya kalsifikasi Myasthenia Gravis Foundation of America (MGFA) dan MG composite score (MG-cs). ${ }^{11,12}$

Peran pemeriksaan anti-AChR sebagai prediktor dan penentuan derajat penyakit MG masih dalam perdebatan. Pada beberapa penelitian terdahulu mengatakan tidak adanya hubungan kadar antiAChR dengan derajat keparahan penyakit $\mathrm{MG}^{9}{ }^{9,13}$ Sebaliknya, penelitian lain mengatakan terdapat hubungan antara kadar anti-AChR dengan derajat keparahan penyakit $\mathrm{MG}$ dan respons terhadap imunoterapi. ${ }^{12,14,15} \mathrm{Hal}$ ini yang mendasari pentingnya penelitian ini dibuat.

Pemeriksaan anti-AChR secara rutin umumnya menggunakan teknik pemeriksaan ELISA. Pada individu yang menunjukkan seronegatif dengan pemeriksaan metode ELISA dapat dilanjutkan dengan pemeriksaan clustered anti-AChR menggunakan metode cell-based assay (CBA). ${ }^{16}$

Saat ini di Indonesia belum rutin dilakukan pemeriksaan serologi antibodi AChR sehingga praktisi klinis tidak mempunyai informasi lengkap untuk pelaksanaan pasien MG. Selain itu penelitian mengenai $\mathrm{MG}$, serologi antibodi $\mathrm{MG}$ dan hubungannya dengan derajat keparahan MG di Indonesia belum ada, sehingga diperlukan penelitan dan pemaparan mengenai hal ini untuk menjadi dasar tatalaksana pasien MG di Indonesia. Penelitian ini bertujuan mengetahui hubungan kadar anti-AChR dengan derajat keparahan penyakit MG berdasarkan MG-cs.

\section{METODE}

Penelitian ini merupakan studi potong lintang (cross-sectional) deskriptif-analitik. Data penelitian merupakan data primer dan sekunder yang didapat dari rekam medis RSUPN Cipto Mangunkusumo (RSCM), Jakarta. Penelitian dilakukan pada bulan Januari 2017-November 2017.

Populasi penelitian ini adalah seluruh pasien MG yang berobat di RSCM. Sampel diambil dari populasi yang memenuhi kriteria inklusi dan memberikan persetujuan terhadap informed consent penelitian. Penentuan sampel dilakukan dengan menggunakan metode non probability sampling jenis konsekutif hingga batas waktu pelaksanaan penelitian. Kriteria inklusi sampel yaitu pasien telah didiagnosis sebagai miastenia gravis dan berusia 18 75 tahun. Subjek dieksklusi apabila pasien mendapat plasmaferesis $<4$ minggu sebelum pemeriksaan antiAChR, dan/atau memiliki penyakit autoimun lain.

Pasien yang telah masuk kriteria inklusi, dilakukan anamnesis, pemeriksaan fisik dan neurologi serta menilai derajat MG. MG-cs menilai 10 item dengan rentang score minimal 0 (paling ringan) dan 
maksimal 48 (paling berat).

Kemudian dilakukan pengambilan sampel darah sebanyak $5 \mathrm{ml}$ dengan menggunakan tabung vacutainer tanpa antikoagulan yang kemudian dikirim ke laboratorium Patologi Klinik RSCM untuk dilakukan pemeriksaan serologi anti-AChR. Pemeriksaan anti-AChR menggunakan metode ELISA dengan menggunakan kit dari Euroimun dengan nomor EA 1435-9601G. Anti-AChR dikatakan seropositif jika didapatkan kadar $\geq 0,4 \mathrm{nmol} / \mathrm{L}$.

Analisis data menggunakan program SPSS versi 20.0. Hubungan antar variabel dianggap bermakna bila $p<0,05$. Pengambilan data penelitian telah mendapat persetujuan dari Komite Etik Fakultas Kedokteran Universitas Indonesia dengan nomor surat 1090/UN2.F1/ETIK/2016 dan izin penelitian dari RSUPN Cipto Mangunkusumo dengan no. L.B.02/10/X.2/0015/2017.

\section{HASIL}

Pada penelitian didapatkan 72 subjek yang memenuhi kriteria inklusi. Proporsi laki-laki dan perempuan adalah 1:2,5 dengan usia termuda 20 tahun dan tertua 74 tahun (Tabel 1). Gejala okular merupakan gejala awal terbanyak (79,2\%) dibanding kelemahan ekstremitas dan gejala bulbar. Median durasi sakit subjek penelitian adalah 3 tahun. Karakteristik demografi subjek penelitian dapat dilihat pada Tabel 1.

Seluruh subjek penelitian mendapat terapi inhibitor asetilkolinesterase dengan dosis $60-420 \mathrm{mg} /$ hari dan hampir $42 \%$ mendapat terapi kombinasi dengan imunosupresan. Terapi imunosupresan yang banyak digunakan adalah kombinasi steroid dengan nonsteroid. Jenis nonsteroid yang banyak dipakai adalah golongan azatioprin. Dari sepuluh gejala klinis yang dinilai dalam MG-cs, hampir sebagian subjek mengeluhkan adanya ptosis dalam waktu $<45$ detik pada salah satu atau di kedua mata (59 subjek). Sebaran gejala klinis yang dinilai berdasarkan MGcs dapat dilihat pada Gambar 1.

Pada Tabel 2 dapat dilihat bahwa sebanyak 59,7\% pasien MG memiliki anti-AChR positif (seropositif) dengan nilai kadar terendah $0,08 \mathrm{nmol} / \mathrm{L}$. Terdapat tiga subjek yang dikeluarkan dari perhitungan

Tabel 1. Karakteristik Demografis Subjek Penelitian $(n=72)$

\begin{tabular}{|c|c|}
\hline Variabel & n (\%) \\
\hline Usia (tahun), Rerata \pm SD & $42,86 \pm 12,565$ \\
\hline \multicolumn{2}{|l|}{ Jenis Kelamin } \\
\hline - Laki-laki & $20(27,8)$ \\
\hline - Perempuan & $52(72,2)$ \\
\hline \multicolumn{2}{|l|}{ Usia Awitan MG } \\
\hline$\bullet<50$ tahun & $56(77,8)$ \\
\hline$\bullet \geq 50$ tahun & $16(22,2)$ \\
\hline \multicolumn{2}{|l|}{ Gejala Saat Awitan } \\
\hline - Okular & $1(2,8)$ \\
\hline - Generalisata & $19(43,2)$ \\
\hline - Bulbar & $24(54)$ \\
\hline Durasi Penyakit (tahun), Median (Min-maks) & $3(0,25-29)$ \\
\hline $\begin{array}{l}\text { Tipe MG } \\
\text { - Okular } \\
\text { - Generalisata } \\
\text { - Bulbar }\end{array}$ & $\begin{array}{c}13(18,1) \\
58(80,6) \\
1(1,4)\end{array}$ \\
\hline MG-cs, Rerata \pm SD & $7,82 \pm 3,91$ \\
\hline Dosis Terapi Inhibitor Asetilkolinesterase (mg/hari),Median (Min-maks) & $240(60-420)$ \\
\hline Terapi Imunosupresan & $30(41,7)$ \\
\hline - Steroid & $10(13,9)$ \\
\hline - Non-steroid & $6(8,3)$ \\
\hline - Steroid dan non-steroid & $14(19,4)$ \\
\hline
\end{tabular}




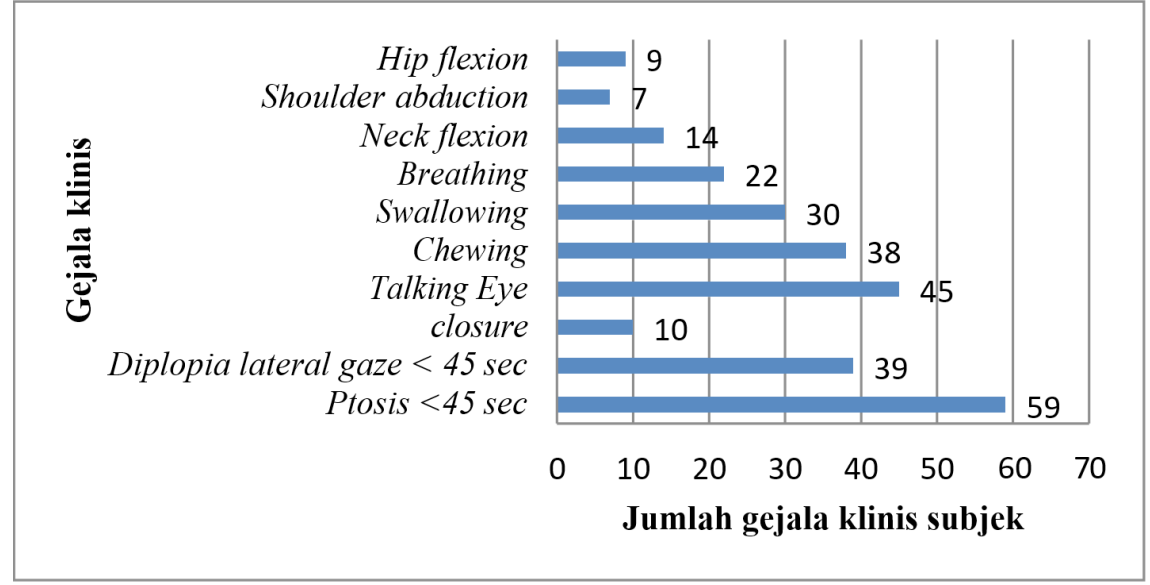

Gambar 1. Grafik Batang Sebaran Gejala Klinis dalam MG Composite Score

Tabel 2. Seropositif Anti-AChR dan Nilai Median Kadar Anti-AChR (n=72)

\begin{tabular}{lc}
\hline \multicolumn{1}{c}{ Karakteristik } & n (\%) \\
\hline Hasil Anti-AChR & $43(59,7)$ \\
- Seropositif & $29(40,3)$ \\
- Seronegatif & $3,78(0,08-786,14)$ \\
Kadar Anti-AChR (nmol/L)(n=69), Median (Min-maks) &
\end{tabular}

statistik karena memiliki nilai kadar anti-AChR yang melebihi batas kuantifikasi alat $(>800 \mathrm{nmol} / \mathrm{L})$. Setelah pengeluaran data nilai ekstrim, berdasarkan uji normalitas Kolmogorov-Smirnov dan grafik q-q plot normal, didapatkan data anti-AChR memiliki distribusi yang tidak normal $(\mathrm{p}<0,05)$.

Untuk melihat adanya hubungan antara kadar anti-AChR dengan MG-cs, dilakukan uji korelasi Spearman dan diperoleh nilai korelasi Spearman sebesar 0,043 dengan $\mathrm{p}=0,727$ (Gambar 2). Hasil ini menunjukkan tidak terdapat korelasi antara kadar anti-AChR dengan nilai MG-cs.

Selanjutnya dilakukan uji analisis MannWhitney untuk melihat perbedaan MG-cs antara pasien yang seropositif anti-AChR dan seronegatif. Pasien dengan seropositif AChR mempunyai nilai median MG-cs lebih tinggi dibandingkan pasien seronegatif AChR namun tidak bermakna secara statistik (Tabel 3). Sehingga disimpulkan tidak terdapat perbedaan bermakna pada nilai MG-cs

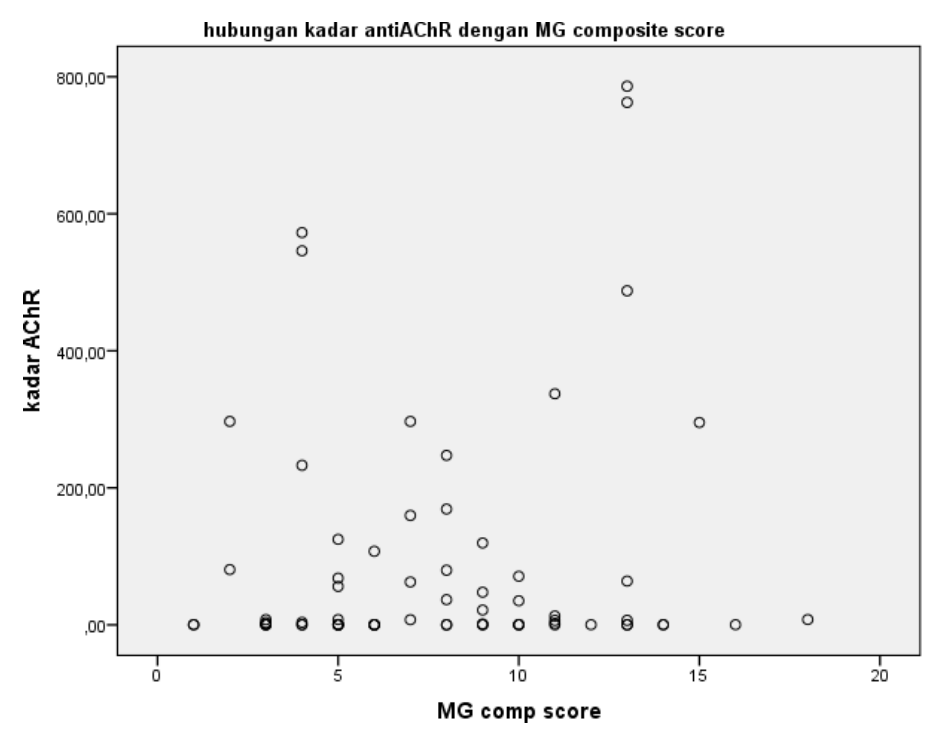

Gambar 2. Grafik Scatter Plot Menggambarkan Kadar Anti-AChR dengan MG Composite Score 
Tabel 3. Hubungan Seropositif Anti-AChR dengan MG Composite Score $(\mathrm{n}=72)$

\begin{tabular}{|c|c|c|c|}
\hline \multirow[b]{2}{*}{ Variabel } & \multicolumn{2}{|c|}{ Anti-AChR } & \multirow[b]{2}{*}{$\mathbf{p}^{*}$} \\
\hline & $\begin{array}{l}\text { Positif } \\
(n=43)\end{array}$ & $\begin{array}{c}\text { Negatif } \\
(n=29)\end{array}$ & \\
\hline MG composite score & $8(2-18)$ & $6(1-16)$ & 0,514 \\
\hline
\end{tabular}

antara subjek dengan seropositif dan seronegatif anti-AChR. Pada tabel 4 menunjukkan bahwa usia awitan dan penggunaan terapi imunosupresan tidak berbeda bermakna secara statistik antara kelompok seropositif dan seronegatif.

\section{PEMBAHASAN}

Rerata usia subjek penelitian yaitu 43 tahun dengan proporsi terbanyak adalah perempuan $(2,5: 1)$. Hal ini sesuai dengan penelitian-penelitian terdahulu yang menunjukkan proporsi perempuan lebih banyak dari laki laki dengan rasio 1,41:1.10,15,17 Penelitian Abukhalil dkk pada 44 subjek MG mendapatkan adanya hubungan bermakna antara jenis kelamin perempuan dengan kejadian MG. ${ }^{18}$

Usia awitan pada penelitian ini dibagi menjadi dua kelompok usia, sesuai dengan pembagian subgrup miastenia gravis, yaitu kelompok usia $<50$ tahun atau early onset MG dan kelompok usia $\geq$ 50 tahun atau late onset MG. Pada penelitian ini didapatkan proporsi MG terbanyak pada early onset $(77,8 \%)$. Dari literatur dikatakan proporsi terbanyak kejadian MG pada kelompok late onset, yaitu sekitar $35-45 \%$ dibandingkan early onset.,19 Sebaliknya, Murai dkk menunjukkan proporsi early onset MG lebih banyak dibandingkan late onset $\mathrm{MG}$ dengan dominasi perempuan. ${ }^{20}$ Early onset $\mathrm{MG}$ dikatakan banyak ditemukan terutama pada populasi Asia dan kemungkinan berhubungan dengan genetik HLADR3,HLA-B8. ${ }^{21}$ Suatu penelitian menunjukkan terdapat hubungan kuat antara Genome Wide Association (GWAS) pada subgrup early onset MG dengan TNFAIP3-interacting protein-1 (TNIP-1) dan lokus B-HLA. ${ }^{22}$

Adanya keterlibatan hormon seks estrogen juga diyakini berhubungan erat dengan early onset $\mathrm{MG}$, kejadian early onset MG berbanding lurus dengan dominasi perempuan. Estrogen berperan penting dalam proses imun yang melibatkan sel $\mathrm{T} 2 \mathrm{CD} 4+$ dan sel B serta mengaktifkan penyakit autoimun yang dimediasi oleh sel B. Dalam kompartemen sel $\mathrm{B}$, estrogen adalah stimulator imun yang berperan dalam maturasi, seleksi dan sekresi antibodi. ${ }^{23}$

Gejala okular merupakan gejala awal tersering pada MG dan dalam 2 tahun dapat berkembang menjadi bentuk generalisata. Pada penelitian ini, gejala okular merupakan gejala awitan terbanyak $(79,2 \%)$ dibandingkan dengan gejala generalisata dan bulbar. Median durasi sakit pada penelitian ini 3 tahun dengan rentang 4 bulan sampai 29 tahun. Hal serupa dikemukakan pada penelitian lain yang mendapatkan gejala awal MG terbanyak adalah gejala okular. ${ }^{3,17,20}$ Gejala okular terjadi saat awitan disebabkan karena neuron motor yang menginervasi otot ekstraokular memiliki frekuensi firing yang tinggi sehingga mudah terjadi kelelahan miastenik. Selain itu, otot ekstraokular terdiri dari serabut tonik yang jika terjadi kehilangan AChR maka akan menghasilkan penurunan potensial pada akhir saraf (endplate) dan terjadilah penurunan kekuatan signifikan pada serabut tersebut. ${ }^{11,14}$

Derajat keparahan MG dapat dilihat secara kuantitatif berdasarkan MG composite score maupun kualitatif berdasarkan klasifikasi MGFa. Pada penelitian ini terdapat hampir seluruh subjek termasuk dalam klasifikasi MGFa sesuai dengan MGFa 2a (38,9\%) dan MGFa 2b (37,5\%). Secara kuantitatif, didapatkan MG composite score dengan rerata $7,82( \pm 3,91)$. Hasil penelitian ini lebih tinggi dibandingkan penelitian Jeong dkk di Korea yang mendapatkan rerata MG composite score 3,74+3,86. Subjek penelitian Jeong dkk ini memiliki durasi MG yang lebih pendek (yaitu $<1$ tahun) dibandingkan penelitian ini. ${ }^{24}$

Seluruh subjek penelitian mendapatkan terapi inhibitor asetilkolinesterase, berupa pyridostigmin dengan rentang dosis 60-420mg per hari. Terapi inhibitor asetilkolinesterase merupakan terapi utama untuk memperbaiki transmisi neuromuskular pada 
MG. Dosis pada penelitian ini sesuai dengan panduan tata laksana $\mathrm{MG}$ pada umumnya yaitu pyridostigmin dapat diberikan dengan dosis 360-450mg terbagi dalam 4-5 dosis per hari. ${ }^{25}$

Pada penelitian ini, hampir separuh subjek penelitian $(41,7 \%)$ mendapatkan terapi imunosupresan dan sebagian besar mendapatkan kombinasi antara steroid dan nonsteroid. Terapi imunosupresan diberikan untuk terapi jangka panjang dengan lini pertama yaitu golongan glukokortisteroid dan azatriopin. Glukokortikoid seperti prednison, prednisolon dan metilprednisolon memberikan perbaikan secara klinis dalam 4-8 minggu pada $70-80 \%$ pasien MG. Penggunaan jangka panjang glukokortisteroid disarankan dikombinasikan dengan obat imunosupresan steroid-sparing atau nonsteroid seperti azatriopin. ${ }^{26}$ Penelitian terdahulu menunjukkan bahwa terapi kombinasi umumnya digunakan sebagai terapi jangka panjang yang efektif terutama untuk MG generalisata. ${ }^{27}$

Pada penelitian ini, seropositif anti-AChR didapatkan pada hampir $60 \%$ subjek. Hasil ini sama seperti pada penelitian yang dilakukan oleh beberapa penelitian lain di Asia dan Eropa yang menunjukkan AChR seropositif pada $>70 \%$ pasien. ${ }^{5-7,15}$ Beberapa kondisi dapat mempengaruhi kadar antibodi AChR, diantaranya adalah keterlibatan antibodi patogen selain anti-AChR dan metode pemeriksaan antibodi yang digunakan. ${ }^{14}$

Pemeriksaan kadar anti-AChR dilakukan dengan menggunakan metoda ELISA dan didapatkan kadar anti-AChR sangat bervariasi dengan rentang yang sangat luas mulai dari $0,08 \mathrm{nmol} / \mathrm{L}$ sampai $>800 \mathrm{nmol} / \mathrm{L}$. Pemeriksaan antibodi AChR dengan metoda ELISA tidak dapat melihat jenis antiAChR yang terlibat. Pemeriksan metoda ini untuk melihat kadar antibodi AChR secara umum. AntiAChR dapat dibagi menjadi tipe binding, blocking dan modulating, dimana tipe binding memegang peranan penting dalam tingkat keparahan penyakit. ${ }^{8,9}$ Diferensiasi tipe antibodi AChR tersebut dapat dilihat dengan pemeriksaan metode radio-imunoassay. Namun penelitian ini tidak melakukan diferensiasi antibodi AChR karena belum tersedia di RSCM. Analisa statistik pada penelitian ini menunjukkan tidak didapatkan adanya hubungan antara kadar anti-AChR dengan keparahan MG berdasarkan MG composite score, dan juga memperlihatkan tidak ada hubungan derajat keparahan dengan seropositif ataupun seronegatif anti-AChR. Pada penelitian ini juga didapatkan tidak ada hubungan antara seropositif anti-AChR dengan jenis kelamin, usia awitan, klasifikasi MG dan tipe MG (okular atau generalisatabulbar). Tidak adanya faktor yang berhubungan terhadap seropositif anti-AChR menunjukkan bahwa produksi antibodi dipengaruhi faktor-faktor lain, diantaranya adalah faktor genetik. Keterlibatan genetik dan etnik sangat mungkin berhubungan dengan produksi antibodi yang berperan. Polimorfisme rs2893321 pada gen B-lymhocyteactivating factor (BAFF) merupakan faktor yang berperan pada diferensiasi sel B yang dapat mempengaruhi produksi antibodi dan progresifitas perjalanan penyakit MG. ${ }^{18,28}$

Pemberian terapi imunosupresan berupa jenis steroid, non-steroid maupun kombinasi tidak memperlihatkan perbedaan antara seropositif AntiAChR dengan seronegatif. Hal ini dapat terjadi karena beberapa kemungkinan. Kemungkinan pertama adalah kadar antibodi di dalam tubuh tidak berkurang walaupun menunjukkan gejala klinis perbaikan. Dikatakan perbaikan gejala berupa meningkatnya kekuatan otot setelah pemberian steroid dapat terjadi dalam 4-6 minggu, namun antibodi yang ada menetap hingga beberapa bulan. ${ }^{25}$ Kemungkinan kedua adalah cara kerja tiap terapi imunosupresan tersebut. Pemberian imunosupresan tidak bertujuan mengurangi kadar kuantitatif anti-AChR dalam tubuh/darah, namun memiliki target spesifik. Steroid bekerja dengan mengurangi produksi sitokin sehingga proses inflamasi yang terjadi akibat ikatan anti-AChR akan berkurang dan kerusakan membran pasca-sinaps yang terjadi minimal. ${ }^{8}$ Azatriopin bekerja dengan cara memblokade sintesis nukleotida dan proliferasi limfosit $\mathrm{T}$, sedangkan mofetil mycofenolate menghambat proliferasi limfosit $\mathrm{T}$ dan B secara selektif. Menilik mekanisme kerjanya, imunosupresan tidak mengurangi jumlah antibodi di dalam tubuh, tetapi mengurangi dan menghambat proses inflamasi dan proliferasi limfosit sehingga 
kerusakan yang terjadi dapat dikurangi dan hal ini akan berefek pada perbaikan gejala klinis walaupun jumlah kuntitatif antibodi di dalam tubuh masih tinggi, seperti yang terlihat pada ketiga subjek yang memiliki kadar anti-AChR ekstrim. Suatu penelitian menunjukkan bahwa pemberian tacrolimus sebagai imunosupresan pada pasien MG dapat menurunkan titer anti-AChR dan memperbaiki derajat keparahan $\mathrm{MG}^{29}$

Penelitian ini merupakan studi potong lintang sehingga peneliti tidak dapat melihat fluktuasi kadar antibodi anti-AChR seiring dengan lamanya pasien menderita MG. Di samping itu, peneliti tidak dapat melihat perbandingan kadar antibodi sebelum dan sesudah pemberian imunosupresan. Oleh karena itu, mungkin diperlukan penelitian lanjutan yang dapat melihat kadar antibodi anti-AChR secara serial.

\section{KESIMPULAN}

Kadar antibodi AChR tidak berhubungan dengan derajat $\mathrm{MG}$, usia onset dan penggunaan terapi imunosupresan.

\section{DAFTAR PUSTAKA}

1. Longo D, Gillhus N. Myasthenia gravis. N Engl J Med. 2016;375:2570-81.

2. Gilhus NE, Verschuuren JJ. Myasthenia gravis: subgroup classification and therapeutic strategies. Lancet Neurol. 2015;14:1023-36.

3. Guo J, Dang D. Current overview of myasthenia gravis and experience in China. Neuroimunn Neuroinflamm. 2014;33:998-1009.

4. Hakim M,Safri AY,Wiratman W. Miastenia gravis. Dalam: Aninditha T, Wiratman W, editor. Buku ajar Neurologi. Jakarta: Departemen Neurologi FKUIRSCM, 2017;2:741-52.

5. Hansen JS, Danielsen DH, Somnier FE, Frøslev T, Jakobsen J, Johnsen SP, dkk. Mortality in myasthenia gravis: A nationwide population-based follow-up study in Denmark. Muscle Nerve. 2016;53:73-7.

6. Liu C, Wang Q, Qiu Z, Lin J, Chen B, Li Y, dkk. Analysis of mortality and related factors in 2195 adult myasthenia gravis patients in a 10-year followup study. Neurol India. 2017;65:518-24.

7. Lo YL, Najjar RP, Teo KY, Tow SL, Loo JL, Milea D. A reappraisal of diagnostic test for myasthenia gravis in a large Asian cohort. J Neurol Sci. 2017;376:153-8.

8. Gilhus NE, Skeie GO, Romi F, Lazaridis K, Zisimopoulou P, Tzartos S. Myasthenia gravisautoantibody characteristics and their implications for therapy. Nat Rev Neurol 2016;12:259-68.

9. Lazaridis K, Tzartos SJ. Autoantibody specificities in myasthenia gravis; implication for improved diagnostics and therapeutics. Front Immunol. 2020;11:212.

10. Chou CC, Su IC, Chou IJ, Lin JJ, Lan SY, Wang YS, dkk. Correlation of anti-acetylcholine receptor antibody levels and long-term outcomes of juvenile myasthenia gravis in Taiwan: a case control study. BMC Neurol. 2019;19:170.

11. Trouth AJ, Dabi A, Solieman N, Kurukumbi M, Kalyanam J. Myasthenia gravis: a review. Autoimmune Dis. 2012:Article ID 874680.doi:10. 1155/2012/874680.

12. Muppidi S. Outcome measures in myasthenia gravis: incorporation into clinical practice. J Clin Neuromusc Dis. 2017;18(3):135-46.

13. Sanders DB, Burns TM. Does change in acetylcholine receptor antibody level correlate with clinical change in myasthenia gravis? Muscl Nerv. 2014;49:483-6

14. Peeler CE, De lott LB, Nagia L, Lemos J. Clinical utility of acetylcholine receptor antibody testing in ocular myasthneia gravis. JAMA Neurol. 2015; 31:120-30

15. Heldal AT, Eide GE, Romi F, Owe JF, Gilhus NE. Repeated acetylcholine receptor antibodyconcentrations and association to clinical myasthenia gravis development. PLOS ONE. 2014;12:e114060.

16. Rodriguez P, Al-Hajjar M, Jayawant S, Buckley C, Hilton-Jones D. Clinical features and diagnostic usefulness of antibodies to clustered aceylcholine receptors in the diagnosis of seronegative myasthenia gravis. JAMA Neurol. 2015;72(6):642-9.

17. Boldingh MI, Maniaol AH, Brunborg C, Dekker L, Heldal AT, Lipka AF, dkk. Geographical distribution of myasthenia gravis in Northern Europe - results from a population-based study from two countries. Neuroepidemiol. 2015;44:221-31.

18. Abukhalil F, Mehta B, Saito E. Gender and ethnicitybased differences in clinical and laboratory features of myasthenia gravis. Autoimmune Dis. 2015;1-4.

19. Sanders,D.Wolfe, G.Benatar,M.International Consensus guidance for management of myasthenia gravis. American Academy of Neurology. 2016;10:111-20.

20. Murai H, Masuda M, Utsugisawa K. Clinical features and treatment status of adult myasthenia gravis in japan. Japan Soc of Neuroimmun. 2014;5;8491.

21. Santos E, Bettencourt A, da Silva AM, Boleixa $\mathrm{D}$, Lopes D, Brás S, dkk. HLA and age of onset in mytasthenia gravis. Neuromuscl Disord. 2017;27(7):650-4.

22. Renton AE, Pliner HA, Provenzano C, Evoli 
A, Ricciardi R, Nalls MA, dkk. Genome-wide association study of myasthenia gravis. JAMA Neurol. 2015;72(4):396-404.

23. Khan D, Ahmed SA. The immune system is a natural target for estrogen action: Opposing effects of estrogen in two prototypical autoimmune diseases. Front Immunol. 2016;6:635.

24. Jeong A, Min JH, Kang YK, Kim J, Choi M, Seok JM, dkk. Factors associated with quality of life people with myasthenia gravis. PLoS ONE. 2018; 13(11):e0206754.

25. Farmakidis C, Pasnoor M, Dimachkie MM, Barohn RJ. Treatment of myasthenia gravis. Neurol Clin. 2018;36(2):311-37.

26. Melzer N, Ruck T, Fuhr P. Clinical features, pathogenesis and treatment of myasthenia gravis: a supplement to the guidelines of the German Neurological Society. J Neurol. 2016;17:130-45

27. Berih-Aknin S, Frenkian-cuvelier M, Eymard B. Diagnostic and clinical classification of autoimmune myasthenia gravis. J Autoim. 2014;30:1-6.

28. Deng H, Wang J, Kong X, Zhang H, Wang T, Tian W, dkk. Association of BAFF rs2893321 polymorphisms with myasthenia gravis susceptibility. BMC Med Gen. 2019;20:168.

29. Yokota K, Fujii Y, Shitara M, Hikosaka Y, Okuda $\mathrm{K}$, Moriyama S, dkk. Analysis of change in antiacetylcholine receptor antibody and effect on myasthenia gravis symptoms by adjusting tacrolimus dosage according to the blood concentration. Neurol Clin Neurosci. 2015;3(5):167-72. 